\title{
SINTESIS DAN UJI POROSITAS SCAFFOLD HIDROKSIAPATIT/ALGINAT
}

Lalita El Milla*, Decky J. Indrani ${ }^{* *}$, Bambang Irawan ${ }^{* *}$

\begin{tabular}{|c|}
\hline Keywords: \\
Scaffolds, Porosity, \\
Hydroxyapatite, \\
Alginate
\end{tabular}

\section{ABSTRACT}

Background: In bone tissue engineering, scaffold is required with a large porosity of $80-90 \%$. The porosity of the hydroxyapatite/alginate scaffold can be affected by the alginate concentration used. The objective of this study was to determine whether hydroxyapatite/alginate scaffolds with alginate concentration of $1 \%$ and $3 \%$ could be synthesized and to determine whether the use of low concentration alginates in hydroxyapatite/alginate scaffolds could increase the scaffold porosity.

Methods: The method used in making scaffold was freeze drying method, while the method used to measure porosity was liquid displacement method

Result: In this study, it was found that hydroxyapatite $/ 1 \%$ alginate scaffolds porosity had greater porosity compared with hydroxyapatite $/ 3 \%$ alginate scaffolds with significant difference.

Conclusion: So, it can be concluded that the use of lower alginate concentration can increase porosity in hydroxyapatite/alginate scaffolds.

\section{PENDAHULUAN}

Maksila dan mandibula merupakan tulang pada manusia yang dapat mengalami kerusakan berupa defek akibat adanya trauma, inflamasi maupun akibat tindakan bedah. Oleh sebab itu, perbaikan tulang mandibula atau maksila menjadi permasalahan klinis ${ }^{1}$. Kerusakan tulang dapat diatasi dengan pencangkokan tulang yaitu dengan autograft, allograft dan xenograft. Autograft menjadi standar emas, namun keterbatasan jumlah menjadi kelemahannya ${ }^{2}$. Sedangkan pada allograft dan xenograft memiliki keterbatasan pada masalah kompatibilitas dan potensi transfer penyakit dari pendonor. Salah satu alternatif penanganan kerusakan tulang adalah dengan rekayasa jaringan tulang ${ }^{3}$.

Dalam rekayasa jaringan terdapat tiga komponen utama yaitu sel, growth factors dan scaffold ${ }^{4}$. Scaffold merupakan struktur tiga dimensi yang berfungsi sebagai kerangka/ template untuk pertumbuhan sel tulang 5 . Untuk memungkinkan terjadinya pertumbuhan sel, scaffold harus memiliki struktur berpori dengan nilai porositas untuk mendukung regenerasi tulang adalah $80-90 \%{ }^{5}$. Diketahui bahwa semakin besar porositas scaffold akan menghasilkan proliferasi dan diferensiasi sel tulang lebih cepat ${ }^{6}$. Untuk menghasilkan scaffold berpori tersebut, digunakan beberapa bahan yang berbeda-beda.

Tulang terdiri dari bahan apatit, oleh karena itu salah satu bahan yang telah dimanfaatkan sebagai bahan scaffold adalah hidroksiapatit yang memiliki kesamaan kimia dan fisika dengan mineral penyusun tulang dan gigi dengan elemen utama berupa kalsium dan fosfor ${ }^{7,8}$. Namun, hidroksiapatit memiliki sifat biomekanik yang lemah yaitu kuat tarik yang rendah dan bersifat brittle serta porositas yang rendah ${ }^{9}$. Oleh karena itu saat ini hidroksiapatit banyak dikombinasikan dengan bahan biopolimer untuk membentuk scaffold 
komposit.

Biopolimer dari alam lebih banyak dipilih sebagai material scaffold karena memiliki sifat biokompatibel, biodegradabel, non toksik dan lebih banyak ketersediaannya dibanding polimer sintetik ${ }^{10}$. Biopolimer tersebut di antaranya adalah alginat. Alginat merupakan polisakarida asidik yang diekstrak dari alga cokelat (Phaeophyceae), termasuk di antaranya Sargassum sp yang banyak ditemukan di perairan Indonesia ${ }^{11}$.

Beberapa peneliti diketahui telah berhasil mempreparasi scaffold hidroksiapatit/alginat dengan porositas yang berbeda-beda 12,13,14. Untuk memperoleh porositas scaffold yang besar dapat dilakukan dengan mengatur konsentrasi biopolimer yang digunakan ${ }^{15,16}$. Lin (2004) membuat scaffold hidroksiapatit/alginat $3 \%$ dengan porositas $82 \%$. Sedangkan Marsich (2013) menghasilkan scaffold hidroksiapatit/ alginat $1 \%$ porositas $80 \%$. Szparaga et al. (2015) menunjukkan bahwa konsentrasi alginat sebesar $8 \%$ memiliki viskositas sebesar 69,69 Pa.s sementara konsentrasi alginat 5 $\%$ memiliki nilai viskositas sebesar 4,12 Pa.s sehingga menunjukkan bahwa semakin rendah konsentrasi alginat maka akan semakin rendah viskositas larutan alginat. Alginat dengan viskositas rendah lebih banyak mengandung air sehingga pada saat proses freeze drying butir-butir air yang menguap diperkirakan akan dapat meninggalkan pori-pori lebih besar.

Dari uraian di atas, porositas diketahui dapat dipengaruhi oleh konsentrasi alginat. Oleh karena itu dengan menggunakan konsentrasi alginat yang rendah, diharapkan dapat menghasilkan scaffold hidroksiapatit/ alginat dengan porositas yang tinggi. Penelitian sebelumnya menggunakan konsentrasi alginat $1 \%$ dan $3 \%$ 12,13,14. Namun belum banyak penelitian yang membandingkan pengaruh kedua konsentrasi tersebut terhadap porositas scaffold hidroksiapatit/alginat.

\section{METODE PENELITIAN}

\section{Bahan Penelitian}

Bahan utama penelitian ini berupa hidroksiapatit diperoleh dari penelitian sebelumnya $^{12}$, yaitu hidroksiapatit yang diperoleh dari pencampuran serbuk $\mathrm{Ca}(\mathrm{OH})^{2}$ dan cairan $\mathrm{H}^{3} \mathrm{PO}^{4}$ dengan metode presipitasi dan dikalsinasi dengan suhu $900^{\circ} \mathrm{C}$ dan alginat yang diekstrak dari Sargassum crassifolium perairan Banten (Balai Besar Riset Pengolahan Produk dan Bioteknologi Kelautan dan Perikanan Republik Indonesia). Jumlah spesimen masing-masing kelompok pada penelitian ini adalah 12, sehingga total sampel berjumlah 24 .

\section{Pembuatan Scaffold Hidroksiapatit/Alginat}

Untuk mendapatkan alginat dengan konsentrasi $1 \%$, 1 gram serbuk sodium aginat ditambahkan 99 gram (DDW), sedangkan untuk memperoleh alginat 3\%,3 gram serbuk sodium alginat ditambah 97 gram DDW. Untuk membuat scaffold hidroksiapatit/ alginat $1 \%$, hidroksiapatit seberat 0,428 gram ditambahkan pada larutan alginat $1 \%$. Sedang untuk membuat scaffold hidroksiapatit/ alginat $3 \%$ hidroksiapatit seberat 1,285 gram ditambahkan pada larutan alginat 3\%. Rasio berat hidroksiapatit/alginat adalah sebesar $30 / 70$. Penambahan hidroksiapatit dilakukan dengan cara dropwise selama satu jam sambil terus diaduk dengan magnetic stirrer (500-100 rpm). Kemudian pengadukan dilanjutkan hingga satu jam pada suhu kamar lalu dihomogenisasi dengan kecepatan putar 3400 rpm selama 5 menit menggunakan homogenizer dan dilanjutkan sonikasi $(20 \mathrm{~Hz})$ selama 2 jam.

Tahapan selanjutnya, dilakukan pencetakan pada 24 well-plate dan dibekukan pada suhu 
-400C selama $2 \times 24$ jam. Selanjutnya dilakukan lyofilisasi selama $3 \times 24$ jam dengan alat freeze dryer (Christ Beta-1 Freeze Dryer, Jerman) pada tekanan 0.1-0.2 torr dengan pengaturan temperatur -400C untuk mensublimasi es dari scaffold komposit. Kemudian pada masingmasing scaffold dilakukan proses crosslinking dengan merendam scaffold pada larutan $0,2 \mathrm{M}$ $\mathrm{CaCl}^{2}$ selama 15 menit kemudian dibilas sebanyak 3 kali dan direndam pada DDW selama 24 jam untuk menghilangkan sisa $\mathrm{CaCl}^{2}$ yang tidak terikat. Scaffold yang basah kemudian dibekukan dan dilakukan lyofilisasi kembali sebagaimana prosedur sebelumnya.

\section{Pengukuran Porositas}

Pengukuran porositas dilakukan dengan metode liquid displacement. Prosedur tersebut adalah sebagai berikut; volume (V0) dan berat (W0) dari sampel diukur. Kemudian sampel direndam dalam ethanol hingga sampel jenuh. Sampel diukur kembali beratnya (W1). Porositas scaffold dihitung dengan rumus :

$$
\text { porositas }(\%)=\frac{\left(W_{1}-W_{0}\right)}{\rho \times V_{0}} \times 100 \%
$$

$\rho$ adalah massa jenis etanol ${ }^{19,20}$. Proses ini dilakukan di Laboratorium biomaterial Pusat Aplikasi Isotop dan Radiasi BATAN

\section{HASIL}

Porositas keempat scaffold sebagaimana ditunjukkan pada Tabel 1

Tabel 1 Hasil perhitungan porositas beberapa jenis scaffold

No. Jenis Scaffold

1. Hidroksiapatit/alginat $1 \%$

2. Hidroksiapatit/alginat $3 \%$
$93.37 \pm 2.36$

$82.39 \pm 1.35$

Berdasarkan ujinormalitas Shapiro-Wilk dan uji homogenitas varian Levene's Test diperoleh hasil distribusi data normal $(p>0,05$ pada semua kelompok scaffold) dan varians homogen ( $p>$ 0,05). Hasil uji T-test menunjukkan bahwa nilai porositas kedua scaffold berbeda bermakna dengan nilai kemaknaan 0,000 $(p<0,05)$.

\section{DISKUSI}

Scaffold yang dibentuk pada penelitian ini merupakan komposit dari hidroksiapatit dan alginat. Pada masing-masing scaffold, partikel hidroksiapatit yang merupakan fasa anorganik terbenam dalam alginat yang merupakan fasa organik. Scaffold hidroksiapatit/alginat terbentuk melalui beberapa interaksi dari bahan yang digunakan. Pembentukan scaffold diperoleh dari mencampur hidroksiapatit dan alginat menghasilkan larutan komposit hidroksiapatit/alginat. Dengan melakukan proses freeze drying maka dihasilkan scaffold berpori. Pada proses perendaman scaffold hidroksiapatit/alginat di dalam larutan kation divalen $\mathrm{CaCl}^{2}$ terjadi interaksi dalam alginat. Dalam hal ini gugus COO- pada alginat saling berinteraksi menyebabkan rantai polimer alginat berikatan satu sama lain dengan $\mathrm{Ca}^{2+}$ yg terenkapsulasi di dalamnya, sehingga membentuk struktur egg-box. Dengan demikian, scaffold berpori terbentuk disertai crosslinking yang mungkin hanya terjadi di permukaan scaffold tersebut.

Scaffold hidroksiapatit/alginat 3\% memiliki Porositas \pm SD (\%) porositas yang tidak jauh berbeda dengan porositas scaffold hidroksiapatit/alginat 3\% yang dihasilkan oleh Lin (2004), yaitu sebesar $82+1,35 \%{ }^{17}$. Sedangkan porositas

Ket $: \mathrm{SD}=$ Standar Deviasi 
pada scaffold hidroksiapatit/alginat $1 \%$ pada penelitian ini memiliki nilai yang lebih besar dari Lin (2004) yaitu $93+2,36 \%$. Porositas yang lebih besar tersebut mungkin disebabkan oleh perbedaan konsentrasi alginat. Semakin tinggi konsentrasi polimer yang digunakan akan menghasilkan porositas yang semakin kecil, sebaliknya semakin rendah konsentrasi yang digunakan maka porositas akan semakin besar ${ }^{16}$.

Porositas scaffold hidroksiapatit/alginat $1 \%$ lebih besar dari porositas scaffold dengan konsentrasi alginat 3\%. Hal ini disebabkan pada larutan alginat $1 \%$ memiliki viskositas yang lebih rendah dibanding larutan alginat $3 \%$. Pada larutan dengan viskositas rendah, terkandung lebih banyak pelarut (DDW), sehingga ketika dilakukan proses freeze drying terjadi sublimasi sehingga meninggalkan pori- pori yang berukuran besar dan jumlah lebih banyak pada scaffold. Porositas scaffold hidroksiapatit/alginat $1 \%$ dan scaffold hidroksiapatit/alginat $3 \%$ yang dihasilkan oleh penelitian ini masih dalam rentang nilai porositas yang menjadi syarat pada scaffold untuk rekayasa jaringan tulang yaitu adalah $80-90 \%{ }^{5}$. Porositas yang besar meningkatkan adanya perlekatan sel yang lebih banyak karena menghasilkan area permukaan scaffold yang lebih luas.

Interaksi antar rantai polimer alginat berupa struktur egg-box yang kemungkinan hanya terjadi di permukaan scaffold dapat berpengaruh pada sifat yang lain yaitu sifat mekanis dan biodegradasi. Hal ini karena scaffold dengan tingkat crosslink yang tinggi atau terdapat lebih banyak struktur egg-box memiliki integritas mekanis scaffold yang lebih baik dibanding scaffold dengan tingkat crosslink yang rendah. ${ }^{21,22}$ Oleh karena itu dibutuhkan studi lebih lanjut mengenai pengaruh perendaman scaffold pada larutan $\mathrm{CaCl}^{2}$ yang dilakukan pada penelitian ini terhadap sifatsifat scaffold hidroksiapatit/alginat seperti sifat mekanis dan biodegradasi.

Penggunaan alginat yang diekstrak dari spesies Sargassum sp menjadi perhatian tersendiri karena spesies tersebut merupakan spesies alga coklat yang banyak terdapat di perairan Indonesia. ${ }^{11} \mathrm{Hal}$ tersebut dapat menekan biaya produksi dari persiapan material alginat dan meningkatkan pemanfaatan bahan alam dari dalam negeri.

\section{KESIMPULAN}

Dari hasil penelitian ini dapat disimpulkan bahwa scaffold hidroksiapatit/alginat $1 \%$ dan scaffold hidroksiapatit/alginat 3\% telah berhasil disintesis. Penggunaan konsentrasi alginat 1\% dapat memperbesar porositas pada scaffold hidroksiapatit/alginat.

\section{DAFTAR PUSTAKA}

1. Tobita M, Mizuno H. Oral and Maxillofacial Tissue Engineering with Adipose-Derived Stem Cells. In: Regenerative Medicine and Tissue Engineering. 2013. p. 141-53

2. Kane RJ, Weiss-bilka HE, Meagher MJ, Liu Y, Gargac JA, Niebur GL, et al. Acta Biomaterialia Hydroxyapatite reinforced collagen scaffolds with improved architecture and mechanical properties q. Acta Biomater. 2015;10-3.

3. Shrivats AR, McDermott MC, Hollinger JO. Bone tissue engineering: State of the union. Drug Discov Today [Internet]. 2014;19(6):7816. Available from: http://dx.doi.org/10.1016/j. drudis.2014.04.010

4. Wu S, Liu X, Yeung KWK, Liu C, Yang X. Biomimetic porous scaffolds for bone tissue engineering. Mater Sci Eng $R$ Reports [Internet]. 2014;80:1-36. Available from: http:// www.sciencedirect.com/science/article/pii/ S0927796X14000503

5. Bose S, Roy M, Bandyopadhyay A. Recent advances in bone tissue engineering scaffolds. Trends Biotechnol [Internet]. 2012;30(10):54654. Available from: http://dx.doi.org/10.1016/j. tibtech.2012.07.005

6. Murphy CM, Haugh MG. The effect of mean pore size on cell attachment, proliferation and migration in collagen glycosaminoglycan 
scaffolds for tissue engineering . 2010;31(3).

7. Krishnamurithy G, Science M, Medicine CC. A review on hydroxyapatite-based scaffolds as a potential bone graft substitute for bone tissue engineering applications. JUMMEC. 2013;16(2):1-6.

8. Sibte S, Abidi A, Murtaza Q. Synthesis and Characterization of Nano-hydroxyapatite Powder Using Wet Chemical Precipitation Reaction. J Mater Sci Technol. 2014;30(4):307-10.

9. Tripathi G, Basu B. A porous hydroxyapatite scaffold for bone tissue engineering: Physicomechanical and biological evaluations. Ceram Int. 2012;38(1):341-9.

10. Venkatesan J, Bhatnagar I, Manivasagan $P$, Kang K, Kim S. Alginate composites for bone tissue engineering : A review. Int J Biol Macromol. 2015;72:269-81.

11. Aufan MR, Daulay AH, Indriani D, Nuruddin A. Sintesis scaffold alginat-kitosan-karbonat apatit sebagai bone graft. J Biofisika. 2012;8(1):16-24.

12. Indrani DJ, Doktor $P$, IImu B, Matematik F, IImu $D$ a N, Alam $P$, et al. Universitas Indonesia Komposit Hidroksiapatit Kalsinasi Suhu Rendah Dengan Sebagai Material Scaffold. Disertasi Progr Dr Bid IImu Mater Fak MIPA Univ Indones. 2012;1-169.

13. Nazarpak MH, Pourasgari F. Fabrication of Tissue Engineering Scaffold from Hydroxyapatite I Alginate Composite. Int J Biosci Biochem Bioinforma. 2014;4(3):142-5.

14. Marsich E, Bellomo F, Paoletti S. Nanocomposite scaffolds for bone tissue engineering containing silver nanoparticles: preparation , characterization and biological properties. 2013;1799-807.

15. Karageorgiou V, Ã DK. Porosity of 3D biomaterial scaffolds and osteogenesis. 2005;26:5474-91.

16. Loh QL, Choong C, Oxon D, Hons M, Mimmm C. Three-Dimensional Scaffolds for Tissue Engineering Applications: Tissue Eng Part B. 2013;19(6):485-502.

17. Hong-Ru Lin1 Y-JY. Porous alginate/ hydroxyapatite composite scaffolds for bone tissue engineering: preparation, characterization, and in vitro studies. J Biomed Mater Res. 2004;52-66.

18. Szparaga G, Sciences C, Metrology T. The Effect of Sodium Alginate Concentration on The Rheological Parameters of Spinning Solution. AUTEX Reseaarch J. 2015;15(2):123-6.

19. Han J, Zhou Z, Yin R, Yang D, Nie J. International Journal of Biological Macromolecules Alginate - chitosan / hydroxyapatite polyelectrolyte complex porous scaffolds: Preparation and characterization. Int $\mathrm{J}$ Biol Macromol. 2010;46:199-205.

20. Kim H, Jung G, Yoon J, Han J, Park Y, Kim $D$, et al. Preparation and characterization of nano-sized hydroxyapatite / alginate / chitosan composite scaffolds for bone tissue engineering.
Mater Sci Eng C. 2015;54:20-5.

21. Mane S, Ponrathnam S, Chavan N. Synthesis and characterization of hypercrosslinked hydroxyl functionalized co-polymer beads. Eur Polym J [Internet]. 2014;59:46-58. Available from: http:// dx.doi.org/10.1016/j.eurpolymj.2014.07.001

22. Lee S, Jo AR, Choi GP, Woo CH, Lee SJ, Kim $B$, et al. Fabrication of $3 D$ Alginate Scaffold with Interconnected Pores using Wire-Network Molding Technique. J Tissue Eng Regen Med. 2013;10(2):53-9. 